\title{
IMUNOSUPRESINIŲ VAISTŲ VARTOJIMAS IR JO SĄSAJOS SU TRANSPLANTATO LAUKIMO TRUKME BEI LAIKOTARPIU PO INKSTO TRANSPLANTACIJOS
}

\author{
Karolina Bagdonavičiūtė ${ }^{1}$, Emilija Biekšaitė ${ }^{1}$, Marius Miglinas ${ }^{1,2}$ \\ ${ }^{l}$ Vilniaus universitetas, Medicinos fakultetas, ${ }^{2}$ Vilniaus universiteto ligoninè Santaros klinikos
}

Raktažodžiai: imunosupresantų vartojimas, inksto transplantacija, recipientas.

\begin{abstract}
Santrauka
Inkstų transplantatų recipientų prognozei ir paties organo išlikimui svarbus imunosupresinių vaistų vartojimas. İvairūs veiksniai, tarp jų - inksto transplantato laukimo trukmè bei po transplantacijos praèjęs laikas gali skirtingai motyvuoti pacientus šiuos vaistus vartoti. Norèdami išsiaiškinti šių veiksnių ịtaką inksto transplantaciją patyrusiems pacientams, atlikome tyrimą, pasitelkdami anoniminị klausimyną. Mūsų imtyje buvo pastebėta, kad pacientai, kuriems transplantacija atlikta palyginti neseniai, palankiau vertina imunosupresinių vaistų vartojimą: rečiau pamiršta juos išgerti, yra labiau patenkinti gydymu, o vaistų vartojimas juos mažiau erzina, palyginus su tais, kuriems transplantacija atlikta seniau.
\end{abstract}

\section{Ivadas}

Pacientų išgyvenamumas po inksto transplantacijos pastaruoju metu padidejo dèl chirurginès technikos patobulèjimo ir efektyvių imunosupresinių vaistų skyrimo, tačiau tinkamas šiu vaistų vartojimas išlieka dideliu iššūkiu [1]. Nustatyta, kad imunosupresinių vaistų vartojimo režimo nesilaikymas po inksto transplantacijos gali būti būdingas daugiau negu 50 proc. visų inkstų recipientų [2]. Netinkamas imuninę sistemą slopinančių vaistų vartojimas padidina inksto transplantato atmetimo epizodu rizika net 7 kartus [3]. Ši problema paveikia pacientų bei transplantatų išgyvenamumą ir ženkliai padidina gydymo išlaidas [1]. Nors netinkamo imunosupresinių vaistų vartojimo rizikos veiksniai varijuoja tarp bendruomenių, tačiau jų identifikavimas gali padèti kurti strategijas, kaip pašalinti, kontroliuoti šiuos veiksnius, padidinti šių vaistų vartojimą, sumažinti išlaidas [1] ir tokiu būdu pagerinti paciento bei inksto transplantato išgyvenamumą [4]. Ne tik gydytojų pateikiama informacija apie vaistus gali daryti ịtaką šiam procesui - pacientų asmeniniai veiksniai, vidinès paskatos, aplinkybès taip pat svarbios. Žinoma, kad gydymo imunosupresiniais vaistais režimo nesilaikymas gali priklausyti nuo amžiaus, lyties, šeimos narių palaikymo, paciento pasitikejjimo gydytojais, vaistų nepageidaujamo poveikio ir kitų veiksnių [2]. Nemažai tyrimų nustatė šių vaistų vartojimo priklausomybę nuo periodo po inksto transplantacijos trukmès $[2,4]$.

Tyrimo tikslas - išsiaiškinti, ar yra ryšys tarp imunosupresinių vaistų vartojimo ir inksto transplantato laukimo trukmès, tarp šių vaistų vartojimo ir laiko, praejusio nuo inksto transplantacijos.

\section{Tyrimo medžiaga ir metodai}

Tyrimas vykdytas Vilniaus universiteto Santaros kliniku konsultacijų poliklinikoje. Tyrime, pasitelkiant netiesiogini, tačiau gana plačiai naudojamą vaistų vartojimą ir gyvenimo būdą padedantị ịvertinti metodą - klausimyną - ieškota imunosupresinių vaistų vartojamumo sąsajų su inksto transplantato laukimo trukme ir laikotarpiu po transplantacijos. Buvo suformuluotos dvi hipotezès: pacientai, kurie ilgai laukè transplantato, tai labiau vertina ir dèl to geriau laikosi gydytojų nurodymų vartodami imunosupresantus; pacientų imunosupresantų vartojimas, didejant laiko po transplantacijos trukmei, darosi prastesnis.

Pas gydytojus nefrologus besilankančių ambulatorinių pacientu (inksto transplantato recipientų) buvo paprašyta, šiems sutikus, užpildyti anoniminę anketą. Anketoje klausta apie pagrindinius demografinius duomenis, transplantacijos priežastį, inksto transplantato laukimo trukmę, laikotarpi po transplantacijos, gretutines ligas, veiksnius, darančius ittaką vartojimui, suinteresuotumą, pacientų požiūrị i gydymą. Surinkti anoniminiai anketų duomenys apdoroti Microsoft Excel ir SPSS statistine programa.

\section{Tyrimo rezultatai ir ju aptarimas}

Tyrimo metu buvo surinktos 87 pacientų užpildytos anketos. 52,9 proc. atsakiusiujų buvo vyriškos lyties, moterys 
sudarè mažesnę dalị pacientų - 47,1 procento. Vidutinis inksto transplantato laukimo laikotarpis mūsų imtyje buvo 26,5 mèn. (1-120 mèn.) $(n=81)$. Vyrų grupejje $(n=43)$ vidutiniškai jis truko 29 mèn. (1-120 mèn.), o moterų grupejje $(\mathrm{n}=36)$ trumpiau -24 mènesius (1-84 mèn.). Anketų pildymo metu vidutiniškai buvo praejję 90 mèn. (1-336 mèn.) $(n=82)$ nuo inksto transplantacijos, vyrų grupeje $(n=42)$ - vidutiniškai 83 mèn. (1-336 mèn.), moterų grupejje $(n=38)$ kiek daugiau - 95 mènesiai (1-252 mèn.).

Daugiausia respondentu $-51,8$ proc. $(n=43)$ gydymu yra patenkinti. Labai patenkinti $-13,3$ proc. $(n=11)$, nei nepatenkinti, nei patenkinti $-26,5$ procento $(n=22)$. Tarp atsakiusiujų i klausimą gydymu labai nepatenkinti ir nepatenkinti iš viso 8,4 procento $(n=7)$. Tarp labai nepatenkintu $(n=5)$ laikotarpio po inksto transplantacijos trukmès mediana sieké 70 ménesių (2-252 mèn.), labai patenkintų $(\mathrm{n}=10)$ mediana buvo 57 ménesiai. Visi, išskyrus vieną, $\mathfrak{i}$ klausimą apie efektyvumą atsakę ( $\mathrm{n}=81$ ) pacientai mano, kad imunosupresinis gydymas yra efektyvus. Tyrejai iš užsienio šalių teigia, kad pacientų tikejjimas imunosupresinių vaistų būtinumu stipriai koreliavo su šių vaistų tinkamu vartojimu [3]. Dauguma $-62,2$ proc. $(\mathrm{n}=51)$ atsakiusiujų mano, kad vaistų vartojimo režimo laikosi gerai, 34,1 proc. $(\mathrm{n}=28)$ - labai gerai. Vidutiniškai režimo laikymąsi ịsivertino 3 pacientai $(3,7 \%)$.

R. Ganjali ir bendraautoriai, kartu su dideliu imunosupresinių vaistų skaičiumi bei žinių apie šių vaistų naudingumą trūkumu, kaip vieną iš svarbiausių veiksnių, darančių įtaką vartojimui, ịvardijo prisiminimą vartoti imunosupresinius vaistus [1]. Kitų tyrejjų duomenimis, užmaršumas buvo pagrindiné problema 81 proc. atvejų [2]. Lietuvoje atlikto mūsų tyrimo metu 89,4 proc. pacientų $(\mathrm{n}=76)$ teigè niekada neužmirštantys išgerti 2 ir daugiau dozių iš eilès. Kad tai pasitaiko, tačiau retai, teigia 9,4 proc. $(n=8)$, kartais $-1,2$ proc. $(\mathrm{n}=1)$. Niekada nevartojantys imunosupresiniu vaistų 2 valandas anksčiau ar vèliau nei numatyta, atsakè 54,2 proc. $(\mathrm{n}=45)$ respondentų, retai $-32,5$ proc. $(\mathrm{n}=27)$, kartais $-8,4$ proc. $(n=7)$, dažnai $-3,6$ proc. $(n=3)$. Vienas atsakè visada vaistus geriantis 2 valandomis anksčiau ar vèliau, negu numatyta. Asmenys, teigiantys, kad niekada nepamiršta vartoti imunosupresinių vaistų, mūsų imtyje sudarè didžiąją daugumą 81,2 proc. ( $(n=65)$, jų laikotarpio po inksto transplantacijos mediana buvo 49 mènesiais mažesnè už retkarčiais pamirštančiujų $(\mathrm{n}=10)$ medianą.

4 pacientai iš atsakiusiujų savo nuožiūra sumažino imunosupresantų dozę. Jų transplantato laukimo mediana 21 mèn. (6-120 mèn.), o tarp nesumažinusiųjų šių vaistų dozès mediana taip pat buvo 21 mèn. (1-84 mèn.). Tik vienas mūsų respondentas savo nuožiūra buvo nutraukęs imunosupresinių vaistų vartojimą. Šis pacientas inksto transplantato laukè 6 mėnesius, o laikotarpio po inksto transplantacijos trukmè buvo pati ilgiausia iš visų apklaustujų - 336 mèn. Užsienio šalių tyrèjai ilgesnę transplantato laukimo trukmę bei ilgesnị laikotarpi po inksto transplantacijos siejo su imunosupresinių vaistų vartojimo režimo nesilaikymu [4], kadangi pastarasis veiksnys galimai susijęs su recipientų teigiamos nuomonès apie gydymą mažejimu laikui bėgant [5]. Pavyzdžiui, A. Kenawy ir bendraautoriai, pabrěžę tęstinio recipientų stebèjimo svarbą netgi stabiliais atvejais, nustatè, kad pacientai, praejjus 8 ar daugiau metu po transplantacijos, mažiau laikèsi gydymo imunosupresiniais vaistais režimo [2]. Mūsų tyrimo metu buvo rasta, kad respondentų, kuriuos erzina imunosupresinių vaistų vartojimas $(n=14)$, transplantato laukimo trukmès mediana buvo kiek mažesnè negu tų recipientų, kurių šių vaistų vartojimas neerzina (22 mèn. prieš 23 mèn.), o laikotarpio po transplantacijos mediana buvo didesnè (85 mèn.) negu tų pacientų ( $\mathrm{n}=63)$, kurie atsakè, jog imunosupresantų vartojimas susierzinimo jiems nekelia (72 mèn.). Atliekant šiuos palyginimus, grupių dydžiai labai skyrèsi. Kalbant apie vaistų vartojimo ịtaką pacientų kasdienėms veikloms, recipientų, kuriems vaistų vartojimas joms netrukdo $(n=52)$, trukmès po transplantacijos mediana siekè 76 mèn. (1-336 mèn.), o tų, kurie atsaké, kad vaistų vartojimas šiek tiek trukdo $(n=24)$, mediana buvo mažesnè -70 mènesių (6-268 mèn.).

Aptariant galimas geresnio imunosupresinių vaistų vartojamumo paskatas, 97,5 proc. $(n=78)$ respondentų atsakè, kad gydytojas jiems suteike pakankamai informacijos apie vaistus ir jų vartojimą, tačiau $13(18,1 \%)$ iš 72 atsakiusiujų teige, kad daugiau informacijos apie ligą ir vaistus juos paskatintų vaistų vartojimo režimo laikytis geriau. 12 pacientų (16,7\% atsakiusiujų) teigè, kad režimo laikytis geriau paskatintų didesnis gydytojų dèmesys. Pacientų, kurie atsaké, kad daugiau informacijos apie ligą ir vaistus juos paskatintų labiau laikytis vaistų vartojimo režimo $(n=13)$, apskaičiuota laikotarpio po transplantacijos mediana buvo 61 men. (6-156 mèn.), o tų, kurie atsakè, kad tai jų nepaskatintu geriau laikytis režimo $(n=59)$, mediana buvo didesnè -108 mėnesiai (1-336 mèn.). Pacientų, kurie atsaké, kad juos paskatintų geriau laikytis režimo didesnis gydytojo dèmesys $(n=12)$, potransplantacinio laikotarpio trukmès mediana buvo 126 mèn. (4-336 mèn.), o tų, kurie atsakè, kad tai jų nepaskatintų geriau laikytis režimo $(n=60)$, mediana siekė 90 ménesių (1-268 mèn.).

\section{Išvados}

1. Mūsų apklaustų pacientų imtyje beveik visi sutiko, kad imunosupresinis gydymas yra efektyvus, o dauguma buvo patenkinti gydymu.

2. Pacientams, kurie labai patenkinti gydymu, inksto 
transplantacija atlikta neseniai, palyginus su tais, kurie gydymu labai nepatenkinti.

3. Respondentams, kurie niekada nepamiršta išgerti imunosupresinių vaistų, laikotarpis nuo inksto transplantacijos buvo trumpesnis, nei retkarčiais pamirštantiems.

4. Recipientų, sumažinusių imunosupresinių vaistų dozę, buvo labai nedaug, tačiau transplantato laukimo mediana tiek tarp sumažinusių, tiek tarp nesumažinusių buvo vienoda. Dèl labai skirtingo grupių dydžio ši išvada turètų būti patikrinta apklausus daugiau pacientų.

5. Respondentai, kuriems po inksto transplantacijos praèjo daugiau laiko, labiau skundèsi, kad vaistų vartojimas juos erzina.

6. Dauguma pacientų teigè, kad gauna pakankamai informacijos apie vaistus ir jų vartojimą iš gydytojų.

7. Mūsų respondentų nuomone, didesnis gydytojo dèmesys pacientams, praejjus ilgesniam laikotarpiui po transplantacijos, galètų paskatinti labiau laikytis imunosupresantų vartojimo režimo.

\section{Literatūra}

1. Ganjali R, Ghorban Sabboagh M, Nazemiyan F, Mamdouhi F, Badiee Aval S, Taherzadeh Z, et al. Factors Associated With Adherence To Immunosuppressive Therapy And Barriers In Asian Kidney Transplant Recipients. ImmunoTargets Ther 2019;8:53-62.

https://doi.org/10.2147/ITT.S212760

2. Kenawy AS, Gheith O, Al-Otaibi T, Othman N, Abo Atya H, Al-Otaibi M, et al. Medication compliance and lifestyle adherence in renal transplant recipients in Kuwait. Patient Prefer Adherence 2019;13:1477-86.

https://doi.org/10.2147/PPA.S209212

3. Griva K, Davenport A, Harrison M, Newman SP. Non-adherence to immunosuppressive medications in kidney transplantation: intent vs. forgetfulness and clinical markers of medication intake. Ann Behav Med 2012;44(1):85-93.

https://doi.org/10.1007/s12160-012-9359-4
4. Mella A, Torazza MC, Finocchietti D, Fop F, Allesina A, Dolla C, et al. Non-adherence assessment to immunosuppressant therapy with a self-report questionnaire and intra-patient variability in renal transplantation: risk factors and clinical correlations. Minerva Urol Nephrol 2021.

https://doi.org/10.23736/S2724-6051.21.04244-2

5. Moradi O, Karimzadeh I, Davani-Davari D, Shafiekhani M, Sagheb MM. Pattern and associated factors of adherence to immunosuppressive medications in kidney transplant recipients at a referral center in Iran. Patient Prefer Adherence 2019;13:729-38.

https://doi.org/10.2147/PPA.S198967

\section{ADHERENCE TO IMMUNOSUPPRESSIVE DRUGS AND ITS CONNECTION TO TIME OF WAITING FOR KIDNEY TRANSPLANT AND THE PERIOD AFTER KIDNEY TRANSPLANTATION}

\section{K. Bagdonavičiūtė, E. Biekšaitė, M. Miglinas}

Keywords: adherence to immunosuppressive medications, kidney transplantation, recipient.

\section{Summary}

Adherence to immunosuppressive drugs is crucial for prognosis of kidney transplant recipients as well as for graft survival. Various factors including duration of waiting for kidney transplant and period of time after kidney transplantation can influence motivation to take immunosuppressive drugs. In order to find out the influence of these factors to the patients who experienced kidney transplantation, we carried out the research with the help of an anonymous questionnaire. In our sample it was noticed that patients who had recently underwent kidney transplantation are more satisfied with immunosupresive treatment. They experience less difficulty remembering to take the medicines and are less likely to be irritated with having to stick to the treatment than the respondents to whom more time since transplantation had already passed.

Correspondence to: karolina.bagd@gmail.com

Gauta 2021-05-25 